Н. Родзевич пропонує програму профільного курсу, під час якого планує використовувати картографічні матеріали атласів і підручників. Він зазначає, що екологічний потенціал можна розкрити за допомогою системи питань та завдань, спрмямованих на аналіз природних $\mathrm{i}$ господарсько-економічних карт [13].

Програму курсу «Економіка та екологія» Т. Кучера було запропоновано в двох варіантах: для середніх загальноосвітніх шкіл задля екологізації змісту географічного курсу та для шкіл екологічного профілю. У ній розглядались питання екологічної діяльності, яка дозволила б найбільш ефективно використовувати природні умови і ресурси за найменших втратах для довкілля [6].

Авторські програми передбачали систематизацію екологічного матеріалу 3 подальшим друкуванням посібників, у яких пропонувались різні форми та методи: лекції, семінари, спільні обговорення ключових проблем. Особливу увагу було приділено вмінню працювати з різними джерелами інформації.

Зміст програм передбачав практичні та самостійні роботи. Значну частину складали групові завдання, передбачалось проведення занять 3 різновіковими групами школярів на місцевості для закріплення знань і набуття практичних навичок $[6 ; 7 ; 13]$.

Проаналізувавши статті аналізованого журналу, ми дійшли висновку, що зростає розуміння ролі екологічних проблем у житті суспільства. Йшлося про екологічні проблеми людства, від результату розв'язання яких залежить доля кожного із нас і доля спільноти. У зв’язку з цим змінюється зміст поняття «екологізація» географії в школі. Екологізація стає провідною метою у формуванні нової концепції освіти, якої можна досягти шляхом корегування програм і підручників за рахунок уведення елементів екологічної освіти. Водночас результати дії аналізованих програм під час урочної та позаурочної роботи залишаються недостатньою мірою дослідженими і потребують подальшого вивчення.

\title{
Література
}

1. Винокурова Н. Ф. Взаимосвязь географических и биологических знаний в экологическом образовании школьников / Н. Ф. Винокурова // География в школе. - 1991. - № 3. - С. 39-44. 2. Дмитревский Ю. Д. Экономическая география СССР в школе / Ю. Д. Дмитревский, В. Д. Сухоруков // География в школе. - 1991. - № 1. - С. 27-30. 3. Журавлев И. К. Учебник на уроке / И. К. Журавлев // География в школе. - 1991. - № 1. - С. 24-27. 4. Камалов Л. Ф. Методические аспекты природоохранного образования / Л. Ф. Камалов // География в школе. - 1991. - №1. - С. 41. 5. Комисарова Т. С. Обучающая природа, или неформальное геоэкологическое образование / Т. С. Комисарова // География в школе. - 1995. - № 3. - С. 55-56. 6. Кучер Т. В. Программа курса «Экономика и экология» / Т. В. Кучер // География в школе. - 1993. - № 3. - С.41-44. 7. Латынов В. Л. «Географическая экология человека»- новый курс для школы / В. Л. Латынов, Н. Е. Латынова // География в школе. - 1992. - № 4-5. - С. 18-23. 8. Моженова А. Б. Концепция базового содержания естествознания основной школы Казахстана / А. Б. Моженова, К. Н. Мамирова, К. А. Сарманова, Д. М. Казахбаева, Ж. Д. Молдабеков // География в школе. - 1993. - № 2. - С. 34-36. 9. Мурашова А. И. Экологизация географических знаний / А.И. Мурашова // География в школе. - 1995. №3. - С. 53-55. 10. Панчешникова Л. М. О новом подходе к методической подготовке студентов в педвузе / Л. М. Панчешникова, И. В. Душина // География в школе. - 1991. - № 2. - С. 30-35. 11. Преображенский В. С. Что нам нужно? Экологические элементы в программе или ведущая роль экологического подхода? / В. С. Преображенський // География в школе. - 1991. - № 3. - С. 37-39. 12. Ривкин Е. Ю. Экологизация школьного географического образования / Е. Ю. Ривкин // География в школе. - 1993. - №3. - С. 29-32. 13. Родзевич Н. Н. Программа профильного курса «Глобальные и региональные экологические проблемы» / Н. Н. Родзевич // География в школе. - 1993. - № 4. - С. 35-37.

\section{ОРГАНІЗАЦІЯ АТЕСТАЦІЇ ПРОФЕСІЙНОЇ ДІЯЛЬНОСТІ ПЕДАГОГІВ У ГРЕЦІЇ}

Проценко О. Б. Організація атестації професійної діяльності педагогів у Греції.

У статті визначено нормативно-законодавчу базу, зміст та умови організації атестації педагогічних кадрів у Греції. Виявлено критерії, за якими здійснюється оцінювання професійної діяльності вчителів. Охарактеризовано основні види атестації (атестація шкільним консультантом та директором школи) і етапи їх реалізації.

Ключові слова: педагог, атестація, післядипломна освіта. 
Проценко Е. Б. Организация аттестации профессиональной деятельности педагогов в Греции.

В статье определена нормативно-законодательная база, содержание и условия организации атестации педагогических кадров в Греции. Выделены критерии, по которым осуществляется оценивание профессиональной деятельности учителей. Охарактеризованы основные виды аттестации (аттестация школьным консультантом и директором школы) и этапы их реализации.

Ключевые слова: педагог, аттестация, последипломное образование.

Protsenko E. B. Assessment of professional activity of educators in Greece.

In this article legal and normative basis, contents and conditions for organization of teachers' assessment in Greece are defined. The criteria of teachers' professional activity assessment are defined. The main forms of assessment (assessment by school counselor and by school principle) and its stages are characterized.

Key words: educator, assessment, postgraduate education.

Політичні й соціально-економічні перетворення на сучасному етапі розвитку Української держави поставили нові завдання перед освітньою системою загалом, оскільки саме ій належить провідна роль у формуванні культурних цінностей особистості, зростанні наукового та інтелектуального потенціалу країни. Ефективне розв'язання завдань освіти здебільшого грунтується на якості кадрового забезпечення навчальних закладів, рівні професійної компетентності педагогів, які реалізують процес підготовки молодого покоління до суспільного ы професійного життя.

У цьому контексті пошук шляхів модернізації системи атестації педагогів набуває особливої актуальності. Тому врахування позитивних ідей Греції щодо розв'язання проблеми атестації педагогічних кадрів в межах становить особливий інтерес.

Дослідженню проблеми педагогічної освіти в Україні присвячено роботи таких науковців, як: К. Віаніс-Трофименко, Л. Даниленко, В. Олійник, М. Романенко. Слід зазначити, що в науково-педагогічній літературі значне місце відводиться вивченню організації атестації педагогічних працівників (Г. Башинський, І. Зайченко); організації підвищення кваліфікації та перепідготовки педагогів в зарубіжних країнах (О. Огієнко, С. Синенко, Л. Сігаєва). У наукових дослідженнях вітчизняних авторів також досліджувалися проблеми педагогічної освіти в Греції, зокрема: особливості розвитку системи народної освіти в Греції (Л. Пуховська); організація початкової та середньої освіти в Греції (О. Матвієнко); розвиток системи вищої освіти в Греції в умовах іiї приєднання до Болонського процесу (Н. Постригач); професійна підготовка вчителя початкових класів у сучасній Греції (Ю. Короткова) та Республіці Кіпр: виявлення особливостей підготовки вчителів-філологів у Республіці Кіпр (І. Соколова); історичний розвиток та сучасний стан системи педагогічної освіти Республіки Кіпр (Н. Воєвутко). Однак, визначення особливостей організації атестації педагогів в Греції $\epsilon$ недостатньо дослідженою проблемою.

Метою статті є визначення змісту та умов організації атестації професійної діяльності педагогів в Греції в межах післядипломної педагогічної освіти.

Греція, як і більшість європейських країн світу, надає великого значення атестації (оцінюванню) учителів (П. Пасіардіс), оскільки оцінювання педагогічних кадрів слугує цілям підвищення якості самої освіти [8, с. 6].

У контексті дослідження вважаємо за доцільне конкретизувати значення поняття «атестація» («оцінювання»). Згідно з законодавчими документами Греції атестація професійної діяльності педагогічних працівників початкової та середньої освіти - це неперервний процес оцінювання якості надання освіти учням та рівня реалізації ії цілей та завдань.

Грецькі науковці (П. Папаконстандину, П. Пасіардіс) погоджуються 3 таким тлумаченням атестації, але додають, що не слід обмежуватися тільки оцінюванням якості викладання шляхом вивчення результатів навчальної діяльності учнів. Іншими словами, за допомогою атестації не досліджується рівень знань та рівень сформованості навичок та вмінь учнів, а взагалі вивчається зміст професійної діяльності вчителя (його знання, цінності, моделі поведінки) [6, с. 39].

Так, Законом № 2986/2002 «Про організацію обласних служб початкової та середньої освіти, атестацію педагогічної діяльності та педагогічних кадрів, підвищення кваліфікації 
вчителів та інші положення» регламентуються дії вчителів, директорів шкіл, шкільних консультантів та інших осіб, які беруть участь в оцінювання педагогічних кадрів [4].

Згідно 3 вищеозначеним Законом мета атестації педагогічних кадрів полягає у таких аспектах: підтримці вчителів у їх прагненні до самопізнання, до визначення рівня власної педагогічної підготовки, формуванні наукової думки, дидактичних навичок i вмінь; формуванні чіткої картини щодо результативності роботи вчителів; спробі вдосконалення методів передачі знань від учителя учням шляхом вивчення їх переконань та ідей; визначенні недоліків у професійній діяльності вчителів та спробі їх ліквідації; визнанні ефективності роботи педагогічних кадрів та наданні ім можливості обійняти адміністративні посади; виокремленні змісту підвищення кваліфікації вчителів залежно від їх потреб; формуванні атмосфери взаємоповаги та довіри в педагогічному колективі.

Згідно з Законом № 2986/2002 пропонується проходити атестацію вчителям початкової та середньої освіти [4]. Переваги надаються: вчителям, яких планують підвищити по службі; педагогам, які планують обіймати адміністративні посади; адміністративним робітникам освітньої галузі; вчителям, які мають бажання атестуватися та іншим педагогічним кадрам, якщо виникає необхідність у проведенні атестації [10, с. 22].

Важливо додати, що в організації атестації та підвищення кваліфікації вчителів беруть участь обласні служби, які є децентралізованими службами Міністерства освіти та релігії, неперервної освіти Греції. Взагалі педагогічна діяльність школи та зокрема вчителя оцінюється двома компетентними органами: Центром педагогічних досліджень та Педагогічним інститутом.

Центр педагогічних досліджень контролює педагогічну діяльність вчителів як на рівні школи, області, так і на національному рівні. Працівники Центру вивчають звіти про атестацію, підготовлені обласними центрами підтримки та планування навчання і власне вчителями шкіл, готують доповіді про атестацію педагогічних кадрів, які направляються до міністра національної освіти та релігії, неперервної освіти Греції.

Педагогічний інститут проводить атестацію діяльності школи та педагогічних кадрів 3 метою підвищення рівня якості освіти та кваліфікації вчителів. У Педагогічному інституті передбачено 70 місць для робітників, які організовують атестацію та підвищення кваліфікації вчителів у межах відкритого нещодавно відділення атестації та підвищення кваліфікації вчителів. Їх компетенція передбачає участь у засіданні комісій щодо повторної атестації вчителів, які оскаржили результати нещодавньої атестації, що проводилася їх начальниками, та відвідування шкіл для надання допомоги вчителям у їхній професійній діяльності [2, с. 168]. Разом ці два освітніх заклади спрямовують зусилля на розвиток та підтримку педагогічної діяльності, використовуючи нові інформаційні й телекомунікаційні технології, сприяють застосуванню інноваційних програм у школах.

Паралельно з Педагогічним інститутом Центр педагогічних досліджень, ураховуючи визначені показники якості освіти, формує анкету, яку заповнюють товариства вчителів всієї країни. Це означає, що анкети адаптовано до кожної школи окремо з урахуванням різних критеріїв оцінювання. Наприклад, по-різному проводиться атестація в спеціальній школі (для дітей з обмеженими можливостями) та в школі, де половина учнів $є$ іноземними громадянами.

Періодичність проходження атестації визначається залежно від стажу роботи вчителя, а саме: учителі, які зараховуються до штату, мають атестуватися один раз за перші два роки; учителі, які працюють, проходять атестацію кожні три роки, якщо їх стаж роботи складає до 14 років; кожні чотири роки - від 15 до 26 років роботи в школі; адміністративні працівники проходять атестацію кожні два роки [4].

Атестацію вчителів проводить шкільний консультант або директор школи, у якій вони працюють. Оцінювання професійного рівня педагога здійснюється за шкалою від 0 до 100 балів за різними критеріями (показниками) [7, с. 49]. У процесі атестації шкільний консультант виставляє бали за наявність таких характеристик:

1) наукова база та знання загальнонаукових категорій;

2) наукова діяльність (навчання, підвищення кваліфікації, публікації тощо);

3) планування та структура навчального процесу (наприклад, планування навчального процесу на основі аналітичної програми на тривалий або короткий термін, зв'язок набутих знань з соціальною реальністю); 
4) гнучкість у викладацькій діяльності (впровадження різноманітних дидактичних методів, використання дидактичного матеріалу відповідно до мети уроку);

5) використання часу та засобів навчання на уроці;

6) застосування педагогічних інновацій - участь в пілотних програмах;

7) правильне управління та використання педагогічної діяльності (діяльність, спрямована на творчість та критичне мислення учителя);

8) якість навчання (активність учнів в навчальній діяльності, діалог та співпраця вчитель-учень, підтримка відповідальності та самостійності учнів у процесі навчання, впровадження колективної праці-співпраці, педагогічно обгрунтовані способи подолання проблем у навчанні учнів);

9) педагогічний клімат у класі (характерні риси відносин вчитель-учень, атмосфера навчання-соціалізації учнів);

10) оцінювання учнів (використання різних методів оцінювання згідно з педагогічними дослідженнями, діалог вчителя 3 учнями щодо результатів оцінювання та їх використання в подальшій навчальній діяльності).

Процес атестації потребує від шкільного консультанта неодноразової присутності на уроках учителя, який атестується (не менше трьох разів на рік), уважно спостерігати за навчальним процесом для того, щоб отримати більш вірогідні результати та запропонувати способи покращення педагогічної діяльності. Директор школи також має право проводити атестацію. Він оцінює педагогічні, організаційні, професійні здатності та здібності педагога за такими критеріями: ініціативність (планування та організація навчальних заходів в школі, використання наочного матеріалу); педагогічна поведінка вчителя (стабільність та послідовність поведінки вчителя під час спілкування з учнями, відсутність елементів деспотичної або занадто покровительської поведінки, формування в учнів бажання участі в шкільному житті); співпраця вчителя 3 учнями та їх батьками. Враховується також послідовність та відповідальність учителя у процесі його професійної діяльності [9, с. 152].

Цікаво, що кожен учасник атестації має право впродовж місяця оскаржити результати процесу оцінювання та висунути вимоги щодо внесення певних змін до змісту доповіді про атестацію або прохання повторно атестуватися. Для розгляду скарг створюються спеціальні комісії. Одна комісія працює на базі обласного управління освітою у складі заступника директора Педагогічного інституту, двох директорів управління освітою для розгляду питань щодо атестації вчителів та директорів шкіл. Інша комісія, членами якої можуть бути консультант Педагогічного інституту та два заступники, розміщується в Педагогічному інституті та працює зі справами про атестацію директорів управлінь освітою та начальників відомств освіти, шкільних консультантів та начальників відділів обласного управління освіти.

Отже, сучасна концепція атестації педагогічних кадрів грунтується на принципах відповідальності та демократичності. Відповідно до чинного законодавства організація атестації педагогічних працівників характеризується впровадженням таких інновацій, як: уведення показників якості професійної діяльності вчителів у школі та на національному рівні (Центр педагогічних досліджень), визначення складників атестації, ліквідація недоліків у професійній діяльності вчителів завдяки підвищенню їх кваліфікації, що проводиться Педагогічним інститутом; установлення співпраці між Центром педагогічних досліджень та Педагогічним інститутом [1].

Аналіз дослідницького матеріалу свідчить про те, що концепція атестації професійної діяльності вчителя заснована на принципі, який наголошує на необхідності поступового переходу атестації до підвищення кваліфікації вчителів.

Так, I. Нерандзис акцентує увагу на тому, що саме шкільний консультант має відповідальність за здійснення такого перетворення. Реалізуючи одночасно дві функції як інспектора та радника вчителів, він повинен проводити діагностування майстерності вчителів та виокремлювати ті компоненти, які потрібно удосконалювати. Шкільний консультант повинен знати, що відбувається в школі та в класі, оскільки без такої інформації неможливо змінити та покращити навчальний процес [3, с. 89].

Отже, найважливішим завданням шкільного інспектора $\epsilon$ виокремлення проблем та дидактичних потреб, які постають у процесі атестації професійної діяльності вчителя, і перетворення їх в мету підвищення кваліфікації педагогічних працівників. Реалізація завдання здійснюється в три етапи. 
1. Підготовка до відвідування школи та заняття, відвідування заняття та спостереження шкільного консультанта.

У процесі підготовки до відвідування уроку вчителя, який атестується, шкільний консультант має заздалегідь ознайомитися з усім педагогічним складом школи, іï директором, представниками від батьківського комітету. Крім того, він має бути проінформованим про місце знаходження, матеріально-технічну базу та умови роботи вчителів тих шкіл, які знаходяться в районі під його контролем; співпрацювати 3 начальником управління та відомства відповідного ному та діму (територіальних одиниць Греції).

Шкільний консультант досить часто зустрічається з учителем, який проходить атестацію, задля встановлення особистісного контакту та відносин довіри для плідної роботи з ним. Про свої візити він сповіщає за кілька днів раніше. Необхідною умовою постає також бесіда шкільного консультанта 3 учителем до уроку (ознайомлення вчителя з критеріями оцінювання) та після, співпраця з іншими педагогічними та адміністративними працівниками школи [9, с. 156].

Під час своєї присутності на занятті шкільний консультант спостерігає за ходом уроку без втручання у навчальний процес. Вже після уроку він аналізує з учителем всі етапи уроку та обмінюються думками щодо вдосконалення професійної діяльності вчителя. Якщо визначена проблема стосується не тільки одного вчителя, а майже всього колективу, вона обговорюється колегіально із залученням до дискусії інших консультантів.

2. Визначення проблеми.

Проблеми у викладацькій діяльності шкільний консультант визначає згідно 3 двома параметрами.

- Визначення критеріїв оцінювання викладацької діяльності вчителя.

Упродовж спостереження шкільним консультантом дій вчителя на уроці він оцінює: соціальну та емоційну поведінку вчителя; спілкування з учнями; поведінку учнів, рівень їх знань та рівень активності на уроці; знання предмета вчителем, планування навчального процесу (дидактичні цілі, завдання, зміст та рівень реалізації педагогічних технологій у процесі навчання, підведення підсумків); педагогічні здібності вчителя; використання підручників та інших засобів навчання, застосування методів особистісно орієнтованого навчання.

Визначення джерела отримання інформації.

Джерелом отримання інформації може бути індивідуальне або колективне діагностування [3, с. 92].

Індивідуальне діагностування професіоналізму вчителя проводиться на основі спеціальних

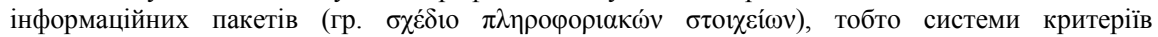
оцінювання, які можуть доповнюватися залежно від ситуації. Однак, слід зазначити, що в такий спосіб шкільний консультант не оцінює майстерність учителя, не засуджує його дії, але об'єктивно визначає сильні та слабкі сторони в його професійній діяльності.

Інформаційний пакет шкільного консультанта складається $з$ двох частин. Перша частина містить інформацію про школу (матеріально-технічна база, кількість класів, план роботи школи на початку року, план проведення уроків певного вчителя тощо), клас (соціальний стан учнів, їх кількість, стать), вчителя (навчання, досвід роботи в освітній галузі, особливі можливості та інтереси, співпраця з колегами, батьками учнів, спільнотою).

Друга, аналітична частина інформаційного пакету, що заповнюється шкільним консультантом після спостереження за навчальним процесом на уроці вчителя, визначається як новий метод атестації педагогічних кадрів. Цей метод зумовлюється виокремленням форм дидактичної поведінки вчителя та основних об'єктів спостереження за навчальним процесом.

У першому випадку (форми дидактичної поведінки вчителя) увага зосереджується на ознаках поведінки вчителя, що визначають його можливості, а саме методи викладання, організація класу та спілкування з учнями [3, с. 99].

У другому випадку (об'єкти спостереження) вивчається продукт викладацької діяльності. Іншими словами, акцентується увага на кінцевих результатах процесу викладання, тобто на покращенні знань учнів або змін у їх поведінці, що відбувається під впливом учителя.

Отже, використовуючи інформаційний пакет та беручи до уваги вищеназвані критерії оцінювання роботи вчителів, шкільний консультант проводить діагностування їх професіоналізму та виокремлює позитивні та негативні характеристики учителів, щоб удосконалити знання та вміння педагогічних кадрів. 
3. Перетворення визначених проблем на цілі підвищення кваліфікації вчителів.

Після відвідування занять учителя, який проходить атестацію, шкільний консультант обговорює з ним всі недоліки уроку та разом вони складають план удосконалення майстерності педагога. Тому підвищення кваліфікації педагогічних кадрів організовується таким чином, щоб учителі могли поповнити свої знання, удосконалити практичні навички та набути певних правил поведінки з учнями.

Г. Ксанфаку пропонує такі способи реалізації програми підвищення кваліфікації вчителів: проведення дослідження, лекції з семінарами, семінар-лабораторія, рольові ігри, відеосеанс 3 метою самооцінювання, складання бібліографії за темою дослідження, укладання каталогу дидактичних методів, взаємне спостереження вчителями за уроками один одного [5, с. 118].

На основі отриманих даних можемо зробити висновок про те, що в Греції здійснюється систематична атестація педагогічних працівників. Система атестації в Греції $\epsilon$ децентралізованою, організація процесу оцінювання майстерності педагогічних кадрів здійснюється різними інститутами освіти та державними установами (Педагогічний інститут, Центр педагогічних досліджень, управління та відомства освіти номів та дімів, школи). Діяльність цих інститутів регламентується державними законами, президентськими наказами та рішеннями міністра освіти та релігії, неперервної освіти Греції.

Атестація вчителів тісно пов'язана $з$ організацією подальшого підвищення їх кваліфікації. Важливу роль при цьому відіграє шкільний консультант, який безпосередньо проводить спостереження за професійною діяльністю вчителя, разом з ним аналізує позитивні та негативні моменти уроків і окреслює коло проблем, для розв'язання яких учитель має відвідати курси підвищення кваліфікації.

До подальших напрямів дослідження належить визначення умов підвищення кваліфікації педагогічних кадрів на базі вищого навчального закладу.

\section{Література}

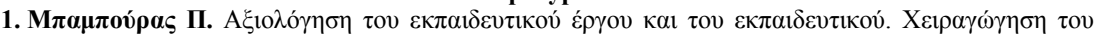

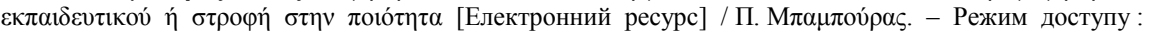

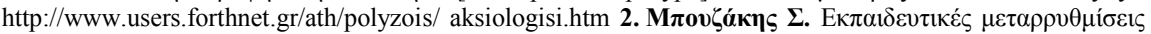

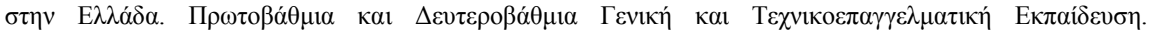

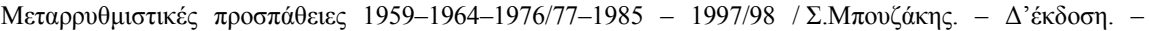

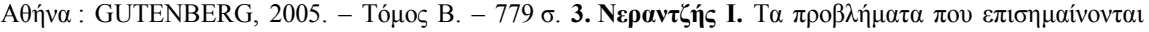

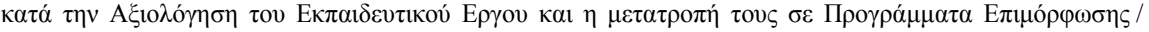

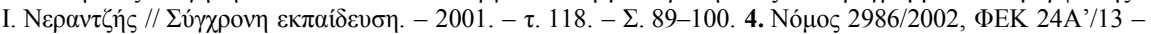

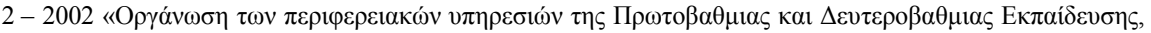

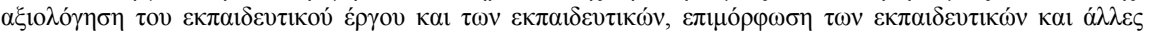

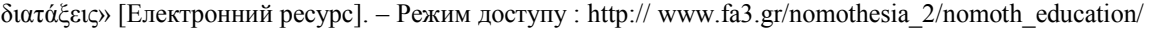

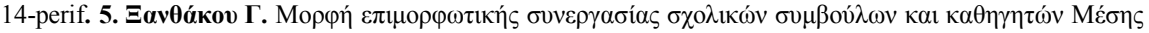

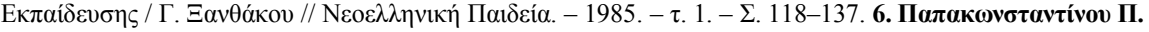

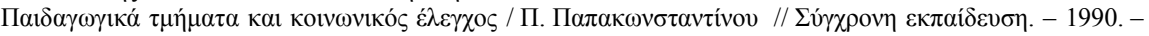

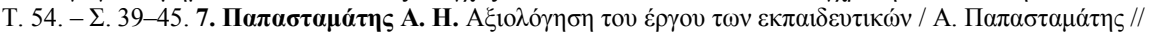

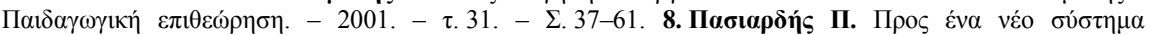

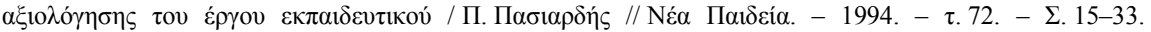

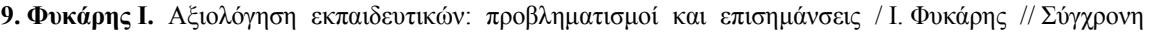

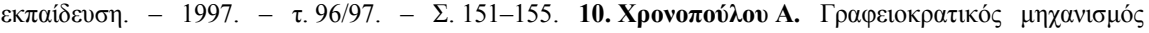

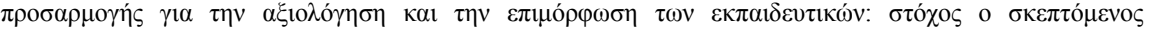

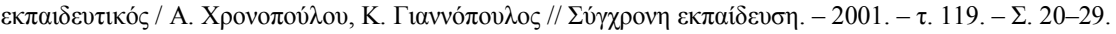

